\title{
13. LATE NEOGENE ENVIRONMENTAL EVOLUTION
}

\author{
Maria Bianca Cita, University of Milano, Department of Geology and Paleontology, Milan, Italy \\ and \\ William B.F. Ryan, Lamont-Doherty Geological Observatory of Columbia University, Palisades, New York
}

\begin{abstract}
An interpretation of the evolution of ocean paleoenvironment during the last $7 \mathrm{~m} . \mathrm{y}$. is presented, based on physical parameters such as carbonate content, grain size, and several indexes arising from the measured variables. Also taken into account are lithologic and acoustic properties of the sediments, quantitative micropaleontological observations on four selected test intervals, and composition in stable isotopes.

Six discrete steps are distinguished from bottom to top, as follows:

Step 1: Late Miocene dissolution event (Section 397-57-3 to Core 397-47).

Step 2: Evidence of a disturbance in the pelagic realm related to the Messinian salinity crisis in the Mediterranean (Cores 397-46 to 397-43).

Step 3: Early Pliocene continuously well-oxygenated stage (Cores $397-42$ to $397-32$ ).

Step 4: Onset of upwelling conditions, of enhanced circulation and progressive climatic deterioration in the late Pliocene (Core 397-31, Section 397-15-3).

Step 5: Early Quaternary, time of upwelling and submarine erosion with climatic cycles without marked cold intervals (Sections 397-15-2 to 397-7-3).

Step 6: Evidence of high-amplitude climatic cycles and of strong climatic deterioration in the late Pleistocene (Sections 397-7-2 to 397-1-1).

Special attention has been paid to Step 2, where a combination of biostratigraphy and paleomagnetic stratigraphy allowed a precise correlation of the Cape Bojador record with a number of Mediterranean events related to the Messinian salinity crisis. Marked, climatically modulated cycles are detected in the latest part of the Messinian, along a cooling trend following a warming trend. The climatic reversal is recorded in the middle part of paleomagnetic Epoch 5, when the Mediterranean was isolated from the World Ocean. Consequently, models are refuted that relate the onset of the Mediterranean salinity crisis to a glacioeustatic lowering of sea level induced by the expansion of ice sheets in Antarctica.

Also discussed in some detail is the Pliocene/Pleistocene boundary (i.e., boundary between Steps 4 and 5) in light of the most recent investigations on the boundary stratotype(s), the philosophy of the "northern guests," and the general climatic trends physically detectable in an oceanic environment.
\end{abstract}

\section{FOREWORD}

One of the major surprises of the deep penetration at Site 397 was that the sediments deposited on an upper continental rise setting stabilized after an important erosional episode and an episode of slope instability and canyon cutting. These sediments consist largely of oozes and marls, deposited at an unusually high sedimentation rate.

Continental rises are considered as sedimentary prisms ". . . consisting of fans or aprons of sediments that have been derived largely from the finer terrigenous silts and clays of the continental shelf, carried downslope by bottom currents and gravitational creep'" (Fair- 
bridge, 1966). This background knowledge is based on detailed investigations conducted on the continental rise bordering the western North Atlantic, where an efficient drainage system was developed on the eastern divide of the North American continent, providing the terrigenous input that is redistributed by various sedimentary processes along the continental rise. This model, however, cannot be applied to the continental margin of northwestern Africa, where the aridity is (and was) such that no efficient drainage system existed during most of the time span considered (Sarnthein, this volume).

At Site 397 , it is only beneath the slumped interval, starting from Core 397-62 downhole, that the autochthonous hemipelagic sediment is accompanied by current transported silt-size and sand-size sediments.

A striking aspect of the monotonous late Neogene succession penetrated is the high rate of sediment accumulation which approximated $80 \mathrm{~m} / \mathrm{m}$.y. in the Pliocene and Quaternary, and dropped to $50 \mathrm{~m} / \mathrm{m}$.y. in the late Miocene. The relatively uniform rates are attributed to high productivity in an area of upwelling.

Fertility of the oceans is controlled by several factors with oceanic circulation playing a major role. Fertility is maximal in areas of upwelling, which are typically developed along the western coasts of the continents. The cool Canary Current, flowing along the northwestern coast of Africa, gives rise to a well-known area of upwelling (Diester-Haass, 1977).

Preserved skeletons of calcareous zooplankton and phytoplankton in the sedimentary column include Coccolithophorids and planktonic foraminifers. In the last 3 m.y., starting with the initiation of Arctic glaciation (Berggren and van Couvering, 1974), siliceous zooplankton and phytoplankton (e.g., radiolarians, silicoflagellates, diatoms) also have contributed to the sediments, though subordinate in quantity to the calcareous plankton.

The hemipelagic sediments under discussion are largely biogenic, but they also contain 30 to 40 per cent clastic components, essentially in the finer fractions. Even taking into account this dilution of the biogenic components, the organic productivity in this area of upwelling is much greater than that recorded in the equatorial Pacific north of Java (DSDP Site 62.1, see Winterer, Riedel, et al., 1971). Also surprising is that this abnormally high organic productivity lasted such a long time.

The lower values of sediment accumulation recorded in the earlier part of the late Miocene are attributed, in part, to dissolution which can be observed in the foraminiferal tests and, in part, to sediment compaction.

\section{OCCURRENCE OF SOME DISCONTINUITIES IN THE MONOTONOUS HEMIPELAGIC SUCCESSION}

Though color, structure, texture, and sediment composition remain basically the same from top to bottom, some discrete intervals are physically detectable in the 550-meter-thick succession under discussion, as follows:
Transition From Biogenic Silica-Bearing to Biogenic Silica-Free Sediments

This transition occurs at approximately 270 to 280 meters sub-bottom. In the coarser sediment fraction, radiolarian tests are recorded starting from Core 397-26 upwards, whereas in smear slides siliceous planktons are first recorded in Core 397-31 (Sarnthein, this volume). This suggests a gradational increase resulting from the progressive development of upwelling conditions.

\section{Transition From Marl-Ooze to Marl-Chalk}

The transition from ooze (unconsolidated) to chalk (semiconsolidated) is considered indicative of incipient diagenesis in pelagic carbonate sediments (Schlanger and Douglas, 1974). It is accompanied by a porosity diminution of 15 to 20 per cent, by dissolution of calcareous microfossils, and overgrowth on calcareous nannofossils (both of the latter processes being controlled by interstitial water). At DSDP Site 167 in the equatorial Pacific (see Winterer, Ewing, et al., 1973), which is used as a reference section for the Schlanger and Douglas diagenetic model, the burial depth of the ooze/chalk transition is 230 meters. This value is comparable, and compatible, with the 300-meter subbottom depth where the boundary between lithologic Unit 1 (marl ooze) and lithologic Unit 2 (marl chalk) is recorded at Site 397 . The dilution caused by the finegrained terrigenous input is responsible for the greater depth of burial at which evidence of incipient diagenesis is recorded.

\section{Occurrence of Acoustic Horizons}

The 550-meter-thick late Neogene succession under discussion encompasses five discrete seismic horizons, designated with the greek letters $\alpha$ through $\epsilon$.

Horizon $\alpha$, recorded at approximately 110 meters sub-bottom and calibrated to Core 397-12, coincides with the boundary between acoustic Units 1 and 2. It is a scour-and-fill surface with angular unconformity (Ryan, this volume) which underlines an erosional gap whose duration is estimated at some 200,000 years, i.e., too short to be detected by biostratigraphic techniques (no biozones are missing) but long enough to develop an abnormal paleomagnetic signal (Hamilton, this volume).

Horizons $\beta, \gamma$, and $\delta$ are recorded within acoustic Unit 2, which is more uniform and less distinctly layered than acoustic Unit 1.

Horizon $\beta$, calibrated at Core 397-24 at approximately 220 meters sub-bottom, also coincides with an erosional gap of short duration, but detectable both biostratigraphically and paleomagnetically because of the high degree of resolution of biostratigraphic subdivisions in the late Pliocene (Mazzei et al., this volume).

Horizons $\gamma$ and $\delta$ are quite minor.

Horizon $\epsilon$ is the top of the slump interval recorded in Section 397-57-3, at 550 meters sub-bottom. It coincides with the boundary between acoustic Units 2 and 3 (see Figure 1). 


\section{OBSERVATIONAL DATA \\ USED AS BASIS FOR THE \\ PALEOENVIRONMENTAL INTERPRETATION}

The following discussion and interpretation focus on a multistep evolution of ocean paleoenvironment, which is summarized in Table 1.

As the basis for the discussion, we used essentially the quantitative observational data worked out at the University of Milano (see Cita and Spezzibottiani; Cita and Colombo; both, this volume). Other data pertinent are found in the contributions by Burckle; Chamley et al., Coradossi and Corazza; Diester-Haass; Sarnthein; Shackleton and Cita (all, this volume, to which references are made). Some of the data from the last contribution will be used when discussing the oceanographic response to the Messinian salinity crisis of the Mediterranean (Step 2 of our model).

Some parameters defined in the two first contributions mentioned are also used here, as follows:

1) Fraction $\mathbf{A}=$ per cent of sediment fraction $>200 \mu \mathrm{m}$

2) Fraction $B=$ per cent of sediment fraction 92 to $200 \mu \mathrm{m}$

3) Dissolution Index $=100-$ Fraction A

4) Dissolution Measure $=$ Fraction $\mathrm{A}-$ Fraction $\mathrm{B}$

5) Grain-Size Ratio $=$ Fraction B/Fraction A

6) Dissolution Ratio = Fraction A: Carbonates $\times 100$

7) Faunal Signal = per cent of constituents of the Tropical Assemblage + Subtropical Assemblage-Subpolar Assemblage (as defined by Thiede, 1977) for the Pleistocene, based on countings of at least 300 specimens from Fraction A; the same with substitute species as discussed by Cita and Colombo (this volume) for the Pliocene.

8) Orbulina universa size $=$ mean diameter and maximum diameter of the last-formed chamber.

Parameters 1 through 6 have been measured on 260 samples, one per section in each core. Parameters 7 and 8 have been measured on 36 samples from four selected test intervals, as shown in Figure 1.

\section{EVOLUTION OF OCEAN PALEOENVIRONMENT}

\section{Step 1: Late Miocene Dissolution Event}

Section 397-57-2 to Core 397-47; sub-bottom depth: 550 to 436 meters (approximately); lower part of lithologic Unit 2; lower part of acoustic Unit 2; upper part of physical properties Unit 5; Age: late Tortonian to early Messinian.

Evidence of dissolution at depth is very strong. The plankton/benthos ratio is unusually low; in Fraction A, it approaches 50 per cent. Entire tests of planktonic foraminifers are rare, and the dissolution index is highest in this interval. The dissolution measure (A B) is strongly negative (see Figure 1).

Dissolution is so advanced that it also affects the carbonate content, which is low. All but two of the data points from beneath 500 meters sub-bottom lie well below the mean value of 57.2 per cent.
The dissolution ratio is lower than 1 throughout the interval (see Figure 1).

Percentages of Fractions A and B and of carbonates vary sympathetically in the lowermost part of the inter$\mathrm{val}$, whereas the correspondence is limited higher in the section.

The low values recorded in Fraction A are partly attributed to incipient diagenesis, in part to a well-known dissolution event recorded in the Atlantic (Berger and von Rad, 1972). No continuously cored sections were available but, on the basis of spot-cored sequences, dissolution appeared to be increasing as a function of increasing age, from the Pliocene to the middle Miocene.

The carbonate cycles with minima recorded in Cores $397-56,397-54$, and 397-52 are above the noise level, being recorded not only as individual data points (see Figure 1 of Cita and Spezzibottiani, this volume), but also in the mean values for each core (ibid., fig. 6).

Sedimentation rate is the lowest recorded for the whole interval under discussion ( 0 to $550 \mathrm{~m}$ sub-bottom).

\section{Step 2: Evidence of a Disturbance in the Pelagic Realm Related to the Messinian Salinity Crisis in the Mediterranean}

Cores $397-46$ to $397-43$; sub-bottom depth: 436 to 399 meters (approximately); middle part of lithologic Unit 2; middle part of acoustic Unit 2; lower part of physical properties Unit 4; Age: middle and late Messinian.

Special attention was paid to this interval, because both authors were interested in investigating the response of the open ocean to the Mediterranean salinity crisis in the Messinian (see Ryan, 1973; Ryan et al., 1974; Cita, 1977; Cita et al., 1977).

The Messinian was calibrated with the greatest possible accuracy using all the microfossils and nannofossils recorded at Site 397 (see Figure 2), and the sequence of magnetic reversals (Salvatorini and Cita; Hamilton; Mazzei et al., all, this volume).

The lower and upper boundaries of the Messinian are correlated biostratigraphically on the basis of calcareous nannofossils. They fall, respectively, in the lower part of Epoch 6 (interpolated age 6.2 m.y.B.P.), in coincidence with the first appearance of Amaurolithus delicatus, and at the top of Epoch 5 (interpolated age 5.2 m.y.B.P.) between the last occurrences of Discoaster quinqueramus and of Triquetrorhabdulus rugosus. Because of dissolution at depth and/or climatic exclusion, planktonic foraminifers could not be used to locate the Messinian boundaries, but the occurrence of two well-calibrated intra-Messinian datum planes substantiate the age assignment.

From bottom to top, we have the coiling change of Globorotalia acostaensis, from predominantly leftcoiling up to Section $397-47-3$ to predominantly rightcoiling from Section 397-47-2 upwards. This datum has been calibrated as the base of Epoch 5 (interpolated at 5.8 m.y.B.P.), both in the Atlantic (Site 397) and in the equatorial Pacific (Core RC 12-66, see Saito et al., 1975). G. acostaensis is recorded in Sicily (Stainforth et 

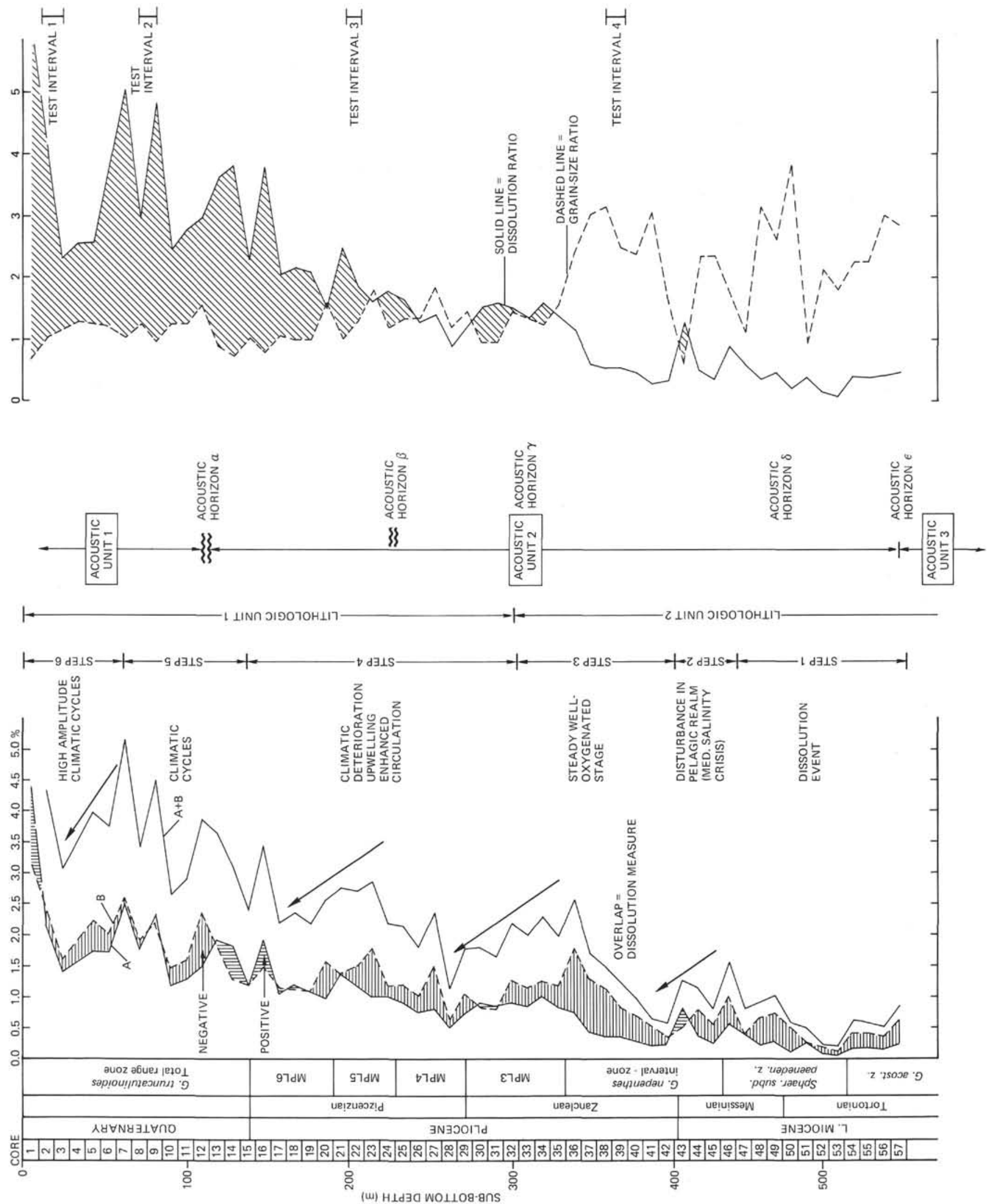


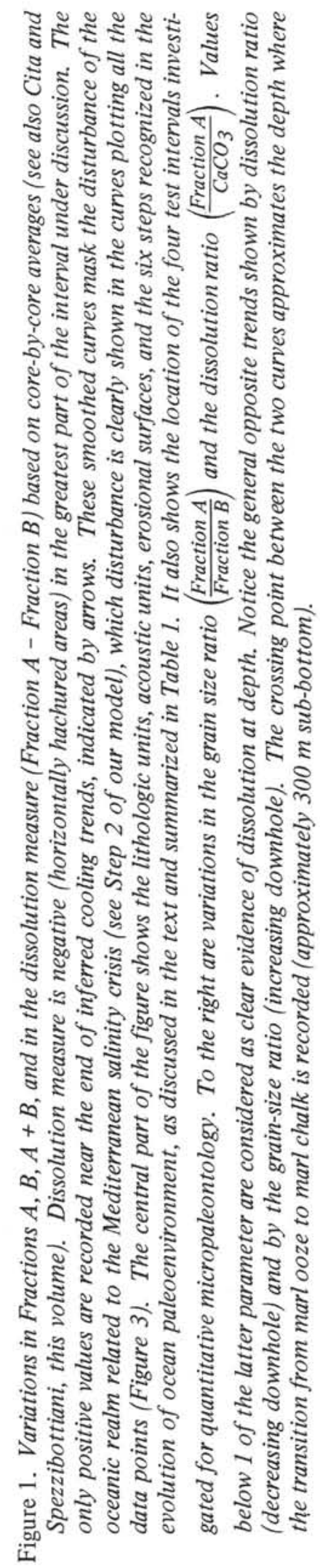

al., 1975) in the Tripoli diatomites, which represent the sedimentary expression of restriction and euxinification of the Mediterranean Basin (see Figure 2, right) prior to the onset of evaporitic conditions. The second foraminiferal datum, calibrated at exactly the same position (with reference to the paleomagnetic scale at DSDP Site 397 and in Core RC 12-66) is the first evolutionary appearance of Globorotalia margaritae at the middle of Epoch 5, with an interpolated approximate age of 5.5 m.y.B.P. Unlike the former, this datum is not recorded in the Mediterranean, which was under evaporitic conditions at that time (see Figure 2, right).

Figure 2 indicates some Mediterranean events pertinent to the following discussion and interpretation. The calibration proposed here shows that the entire duration of the Messinian salinity crisis in the Mediterranean does not exceed $0.5 \mathrm{~m}$.y. The duration of the deposition of the lower evaporitic series, of the main salt body, and of the upper evaporitic series, which is characterized in the Eastern Mediterranean by Paratethyan immigrants (Cita, 1978; Cita et al., 1978), cannot be calculated with precision, since we cannot use biostratigraphic criteria for the Mediterranean record. However, their relative stratigraphic position is clear and unambiguous. Since their total duration is of the order of $0.5 \mathrm{~m} . \mathrm{y}$., the relative duration of each is of the order of one to two hundred thousand years.

Figure 3 displays the variations recorded for this interval in (a) Fraction A, (i.e., relative abundance of large-sized, unbroken tests of planktonic foraminifers, the fraction being dominantly planktonic), (b) carbonate content, and (c) $\delta^{18} \mathrm{O}$ calculated for benthic foraminifers (see Shackleton and Cita, this volume).

The frequency of sampling ensured a data point for approximately every 20,000 years, even less for the isotopic signal where additional samples were processed to clarify the record. The interpretation of these parameters, and of the variations recorded in this particular time span, requires some background explanations.

1) Mediterranean-type marginal basins, land-locked and subject to excess evaporation, are considered the principal source of dense, salty water to the abyssal circulation (Rooth, 1978). The disconnection of the Mediterranean from the World Ocean during the salinity crisis Hsü et al., 1973) deprived the North Atlantic of its main source of dense, warm, deep water. Expected consequences of this paleoceanographic event include (a) cooling of deep water masses in the Atlantic and (b) enhancement of the north-south thermal gradient in the superficial water masses.

2) Though models proposed for the origin of Messinian age evaporites in the Mediterranean include a brine reflux model (Selli, 1973; Sonnenfeld, 1974; Debenedetti, in press) and a multistep model with an early reflux stage (van Couvering et al., 1976), we could prove that desiccation, involving disconnection of the water level, occurred right from the beginning of the salinity crisis (see Ryan et al., 1974; Cita et al., 1978; Hsü et al., 1977). This proof is based on (a) evidence of subaerial exposure recorded in the stratigraphically lowermost 
TABLE 1

Summary of Observational Data From Hole 397 Used to Distinguish Various Steps in the Evolution of the Ocean Paleoenvironment

\begin{tabular}{|c|c|c|c|c|c|c|c|c|c|c|c|c|c|c|c|}
\hline \multirow{2}{*}{$\begin{array}{c}\text { Steps } \\
\text { Recognizable } \\
\text { in Evolution } \\
\text { of Ocean } \\
\text { Paleoenvironment }\end{array}$} & \multirow[b]{2}{*}{$\begin{array}{c}\text { Cores } \\
\text { of } \\
\text { Sections }\end{array}$} & \multirow[b]{2}{*}{$\begin{array}{c}\text { Sub-Bottom } \\
\text { Depth }(m)\end{array}$} & \multirow[b]{2}{*}{ Carbonates } & \multirow[b]{2}{*}{$\begin{array}{c}\text { Dissolution } \\
\text { Index } \\
(100-\text { Fraction A) }\end{array}$} & \multirow[b]{2}{*}{$\begin{array}{l}\text { Dissolution } \\
\text { Measure } \\
\text { (A-B) }\end{array}$} & \multirow{2}{*}{$\begin{array}{c}\text { Grain-Size } \\
\text { Ratio } \\
\frac{B}{A}\end{array}$} & \multirow{2}{*}{$\begin{array}{c}\text { Dissolution } \\
\text { Ratio } \\
\text { A: Carbonates } \\
\times 100\end{array}$} & \multicolumn{2}{|c|}{$\begin{array}{l}\text { Data From } 4 \text { Selected } \\
\text { Test Intervals }\end{array}$} & \multirow{2}{*}{\multicolumn{2}{|c|}{ Acoustic Characters }} & \multicolumn{3}{|c|}{ Lithologic Characters } & \multirow[b]{2}{*}{ Other } \\
\hline & & & & & & & & Faunal Signal & $\begin{array}{c}\text { Orbulina } \\
\text { universa } \\
\text { Size }\end{array}$ & & & & $\begin{array}{l}\text { Lithologic C } \\
\text { Biogenic } \\
\text { Silica }\end{array}$ & Pyrite & \\
\hline $\begin{array}{l}\text { Step } 6 \\
\text { Evidence of high } \\
\text { amplitude cycles } \\
\text { and of strong } \\
\text { climatic deteri- } \\
\text { oration in the } \\
\text { late Pleistocene. }\end{array}$ & 7.2 & 60 & $\begin{array}{l}\text { High-amplitude } \\
\text { cycles. }\end{array}$ & $\begin{array}{l}\text { Strongly variable, } \\
\text { with lowest values } \\
\text { of the entire } \\
\text { section. }\end{array}$ & $\begin{array}{l}\text { Strongly variable, } \\
\text { mostly negative, } \\
\text { but positive at } \\
\text { the top. }\end{array}$ & $\begin{array}{l}\text { Small amplitude } \\
\text { changes, consis- } \\
\text { tently lower } \\
\text { than dissolution } \\
\text { ratio. }\end{array}$ & $\begin{array}{l}\text { Strongly variable, } \\
\text { consistently high- } \\
\text { er than grain- } \\
\text { size ratio. }\end{array}$ & $\begin{array}{l}\text { High amplitude } \\
\text { cycles (from } \\
-26 \text { to }+68) \\
\text { with warmest } \\
\text { and coldest } \\
\text { conditions. }\end{array}$ & $\begin{array}{r}\text { Mean of mean } \phi \\
430 \mu \mathrm{m} \\
\text { Mean of } \max . \phi \\
623 \mu \mathrm{m}\end{array}$ & 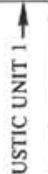 & $\begin{array}{l}\text { Strongly bedded } \\
\text { unit. }\end{array}$ & 1 & 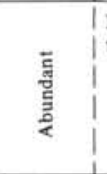 & $\begin{array}{l}\text { Low with fluc- } \\
\text { tuations. }\end{array}$ & \\
\hline $\begin{array}{l}\text { Step 5 } \\
\text { Early Quaternary: } \\
\text { a time of up- } \\
\text { welling and sub- } \\
\text { marine erosion } \\
\text { and climatic } \\
\text { cycles without } \\
\text { marked cold } \\
\text { intervals. }\end{array}$ & $15-2$ & 140 & $\begin{array}{l}\text { Fluctuations } \\
\text { smaller than in } \\
6, \text { most data } \\
\text { points lower } \\
\text { than general } \\
\text { average. }\end{array}$ & $\begin{array}{l}\text { Variable, fluc- } \\
\text { tuating. }\end{array}$ & $\begin{array}{l}\text { Variable, alter- } \\
\text { natively nega- } \\
\text { tive and posi- } \\
\text { tive. }\end{array}$ & $\begin{array}{l}\text { Small amplitude } \\
\text { changes, consis- } \\
\text { tently lower } \\
\text { than dissolution } \\
\text { ratio. }\end{array}$ & \begin{tabular}{|l|} 
Variable, consis- \\
tently higher than \\
grain-size ratio.
\end{tabular} & $\begin{array}{l}\text { Medium ampli- } \\
\text { tude cycles } \\
\text { without cold } \\
\text { peaks (from } \\
+7 \text { to }+52 \text { ). }\end{array}$ & $\begin{array}{r}\text { Mean of mean } \phi \\
432 \mu \mathrm{m} \\
\text { Mean of } \max . \phi \\
655 \mu \mathrm{m}\end{array}$ & $\sum_{i}^{8}$ & $\begin{array}{l}\text { Horizon a at } \\
\sim 110 \mathrm{~m} \text { (scour } \\
\text { and surface } \\
\text { with angular } \\
\text { unconformity). }\end{array}$ & 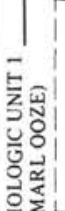 & 蒿 & $\begin{array}{l}\text { Variable down- } \\
\text { hole increasing. }\end{array}$ & \\
\hline $\begin{array}{l}\text { Step } 4 \\
\text { Onset of up- } \\
\text { welling condi- } \\
\text { tions, of en- } \\
\text { hanced circula- } \\
\text { tion and pro- } \\
\text { gressive climatic } \\
\text { deterioration in } \\
\text { the late Pliocene. }\end{array}$ & $15-3$ & 140 & $\begin{array}{l}\text { Fluctuations } \\
\text { as large as in } 5 \\
\text { in the later part } \\
\text { of the interval, } \\
\text { downhole de- } \\
\text { creasing in } \\
\text { amplitude; } \\
\text { general trend } \\
\text { in downhole } \\
\text { increasing } \\
\text { values. }\end{array}$ & $\begin{array}{l}\text { Fluctuations } \\
\text { decreasing in } \\
\text { amplitude down } \\
\text { section. }\end{array}$ & $\begin{array}{l}\text { Variable, general } \\
\text { trend towards } \\
\text { downhole de. } \\
\text { creasing values, } \\
\text { mostly negative. }\end{array}$ & $\begin{array}{l}\text { Variable, most- } \\
\text { ly lower than } \\
\text { dissolution } \\
\text { ratio. }\end{array}$ & $\begin{array}{l}\text { Variable, mostly } \\
\text { higher than } \\
\text { grain-size ratio. }\end{array}$ & $\begin{array}{l}\text { Cooler than in } \\
\text { 5: medium } \\
\text { amplitude } \\
\text { cycles (from } \\
-18 \text { to }+25 \text { ). }\end{array}$ & $\begin{array}{r}\text { Mean of mean } \phi \\
451 \mathrm{\mu m} \\
\text { Mean of } \max . \phi \\
748 \mu \mathrm{mm}\end{array}$ & & $\begin{array}{l}\text { Horizon } \beta \text { at } \\
\sim 220 \mathrm{~m} \\
\text { (erosional sur- } \\
\text { face). }\end{array}$ & | & 吾 & $\begin{array}{l}\text { Fluctuating } \\
\text { highest values } \\
\text { near the base } \\
\text { of the interval. }\end{array}$ & $\begin{array}{l}\text { Strong reworking } \\
\text { in Core } 27 \text {. }\end{array}$ \\
\hline $\begin{array}{l}\text { Step } 3 \\
\text { Early Pliocene } \\
\text { steady well- } \\
\text { oxygenated } \\
\text { stage. }\end{array}$ & 42 & 399 & $\begin{array}{l}\text { Consistently } \\
\text { high values, } \\
\text { downhole in- } \\
\text { creasing varia- } \\
\text { tions at a noise } \\
\text { level. }\end{array}$ & $\begin{array}{l}\text { Small-scale } \\
\text { fluctuations } \\
\text { (noise?). }\end{array}$ & $\begin{array}{l}\text { Steady, down- } \\
\text { hole increasing, } \\
\text { negative. }\end{array}$ & $\begin{array}{l}\text { Downhole in- } \\
\text { creasing mostly } \\
\text { higher than } \\
\text { dissolution } \\
\text { ratio. }\end{array}$ & $\begin{array}{l}\text { Downhole de- } \\
\text { creasing, mostly } \\
\text { lower than } \\
\text { grain-size ratio. }\end{array}$ & $\begin{array}{l}\text { Warmest of the } \\
\text { four test inter- } \\
\text { vals, low ampli- } \\
\text { tude cycles } \\
\text { (from }+15 \text { to } \\
+58 \text { ). }\end{array}$ & $\begin{array}{r}\text { Mean of mean } \phi \\
369 \mu \mathrm{m} \\
\text { Mean of } \max . \phi \\
687 \mu \mathrm{m}\end{array}$ & 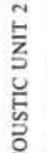 & $\begin{array}{l}\text { Horizon } \gamma \text { at } \\
\sim 310 \mathrm{~m} .\end{array}$ & $i$ & & Absent & $\begin{array}{l}\text { "Noiss" related } \\
\text { to dissolution } \\
\text { at depth affect. } \\
\text { ing O . universa } \\
\text { signal. }\end{array}$ \\
\hline $\begin{array}{l}\text { Step } 2 \\
\text { Evidence of a } \\
\text { disturbance in } \\
\text { the pelagic } \\
\text { realm induced by } \\
\text { the Messinian } \\
\text { salinity crisis in } \\
\text { the Mediter- } \\
\text { ranean. }\end{array}$ & 46 & 436 & $\begin{array}{l}\text { Strong changes } \\
\text { (two major cy. } \\
\text { cles with dura- } \\
\text { tion of the } \\
\text { order of } 1 \times 10^{5} \\
\text { yr), most data } \\
\text { above general } \\
\text { average. }\end{array}$ & $\begin{array}{l}\text { Strong cycles in } \\
\text { the latest part of } \\
\text { the interval } \\
\text { generally high. }\end{array}$ & $\begin{array}{l}\text { Strongly variable, } \\
\text { mostly negative } \\
\text { but very positive } \\
\text { in the latest part } \\
\text { of the Messin. } \\
\text { ian. }\end{array}$ & $\begin{array}{l}\text { Strongly vari- } \\
\text { able, lower } \\
\text { than dissolu- } \\
\text { tion ratio in } \\
\text { the latest } \\
\text { part of the } \\
\text { Messinian. }\end{array}$ & $\begin{array}{l}\text { Strongly variable, } \\
\text { higher than } \\
\text { grain-size ratio } \\
\text { in the latest part } \\
\text { of the Messin- } \\
\text { ian. }\end{array}$ & & & E & & 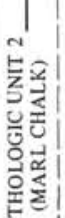 & 攈 & Strongly varíable. & \\
\hline $\begin{array}{l}\text { Step I } \\
\text { Late Miocene } \\
\text { dissolution. }\end{array}$ & $\begin{array}{l}47 \\
57 \cdot 3\end{array}$ & 550 & $\begin{array}{l}\text { Downhole de- } \\
\text { creasing, impor- } \\
\text { tant cycles from } \\
\text { Core } 52 \text { down. }\end{array}$ & $\begin{array}{l}\text { Very high, with } \\
\text { minor changes. }\end{array}$ & $\begin{array}{l}\text { Variable, persis- } \\
\text { tently negative. }\end{array}$ & $\begin{array}{l}\text { Strongly vari- } \\
\text { able, consistent- } \\
\text { ly higher than } \\
\text { dissolution } \\
\text { ratio. }\end{array}$ & 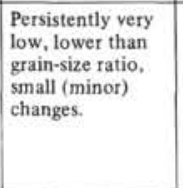 & & & & $\begin{array}{l}\text { Horizon } \delta \text { at } \\
\sim 480 \mathrm{~m} \text {. } \\
\text { Horizon } \epsilon \text { at } \\
\sim 550 \mathrm{~m} \text {. } \\
\text { Top of Unit } 3 \text {. }\end{array}$ & 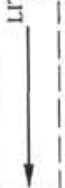 & & $\begin{array}{l}\text { Very high from } \\
\text { Core } 52 \text { down. }\end{array}$ & $\begin{array}{l}\text { Lowest sedi- } \\
\text { mentation rate } \\
\text { of the whole } \\
\text { section. }\end{array}$ \\
\hline
\end{tabular}



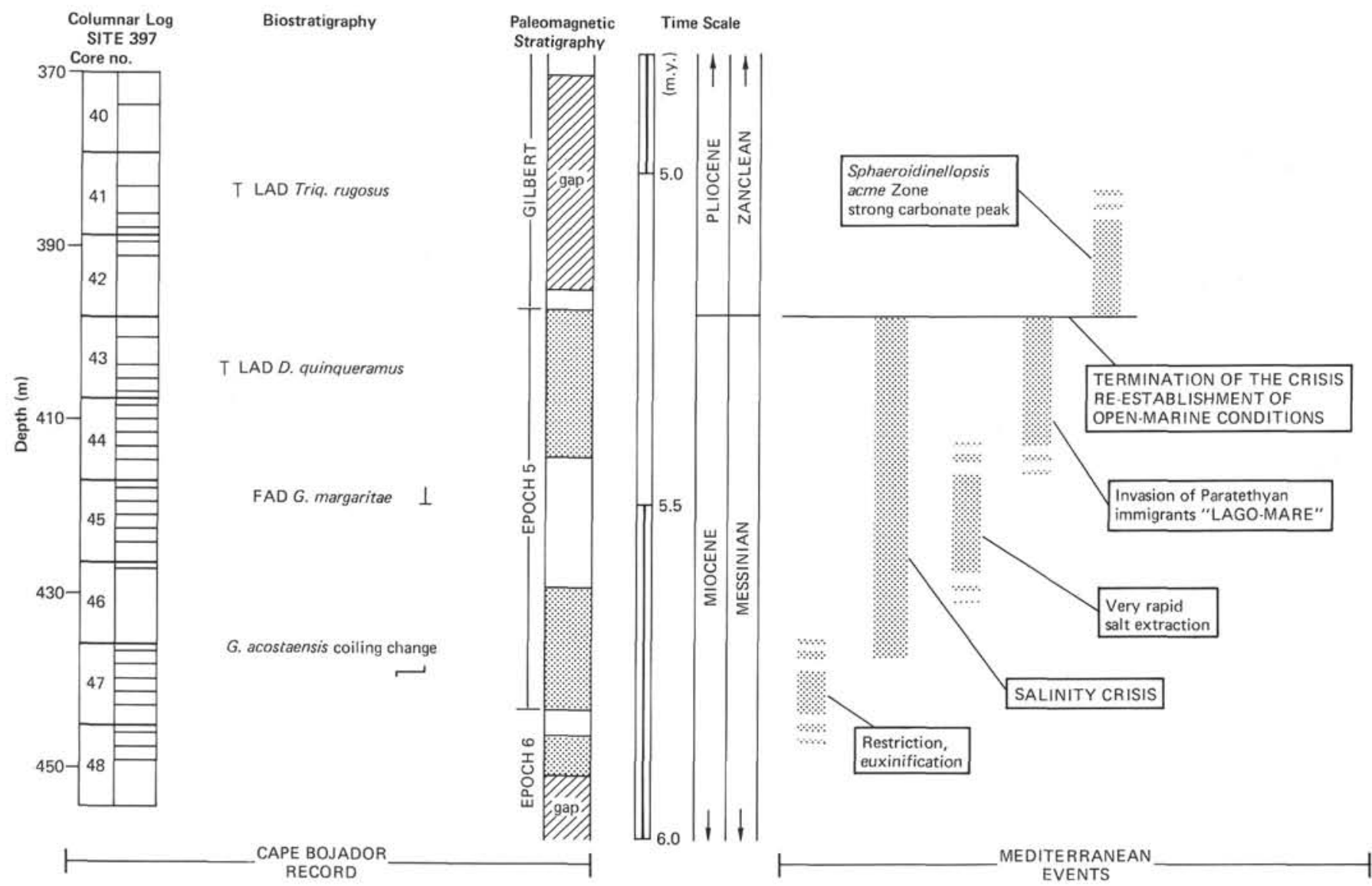

Figure 2. Biostratigraphic and paleomagnetic calibration of the latest Miocene and earliest Pliocene strata continuously cored at DSDP Site 397 (Cape Bojador). At the right, the main Mediterranean events which occurred during this time span are indicated. The calibration demonstrates that the entire salinity crisis had a duration of approximately $5 \times 10^{5} \mathrm{yr}$. The total duration of the salt extraction and of the "Lagomare" stage are more difficult to evaluate, since we have no reliable biostratigraphic criterion to follow in the Mediterranean, and no paleomagnetic record has been worked out so far. Their relative position, however, is well established and controlled in surface and subsurface sections.

evaporitic rocks, and (b) erosional surfaces (on the Mediterranean margins and extending towards the center of the major basins) which are developed beneath the main salt layer (Ryan and Cita, 1978; Ryan, 1978).

3) The volume of the Mediterranean evaporite, calculated at 1 million cubic kilometers (Ryan, 1973), lowered the salinity of the World Oceans by 6 per cent. This decrease in salinity should have had important climatic repercussions, as discussed by Ryan et al. (1974), such as raising the freezing point of sea water, increasing the extension of sea ice, and thus increasing the albedo of the earth and impeding the transfer of heat into the atmosphere (Weyl, 1968). This effect is similar to that discussed in the first explanation (above) and results into climatic deterioration.

4) The existence of a late Miocene cooling phase in the Southern hemisphere has been paleontologically documented for a long time (Bandy, 1966). The Kapitean stage of New Zealand documents a late Miocene regression (Kennett, 1967) and Glomar Challenger drilling in the Ross Sea in 1973 provided new data (Hayes, Frakes, et al., 1975). A definite regressive cycle is also recorded in the generalized curve of Vail and Mitchum
(1978) and corresponds to a change in diagenetic potential detected in the equatorial Pacific deep-sea record ("b" reflector of Schlanger and Douglas, 1974). In most cases, however, the late Miocene regressive phase is not really well dated (see Adams et al., 1977).

Among the best-dated regressive phases are those recorded in land sections facing the eastern North Atlantic. In the Andalusian stratotype section Berggren and Haq (1976) documented a glacio-eustatically induced lowering of sea level estimated approximately 50 meters, whereas in the Bou Reg Reg section of Morocco, Cita and Ryan (1978) described climatically modulated cycles post-dating the first evolutionary occurrence of Globorotalia margaritae, accompanied by evidence of a marked cooling. Based on the above, we can now interpret the curves of Figure 3.

The isotopic curve to the right clearly shows a trend towards lighter isotopic values (warming trend, indicated by an arrow) followed upwards by a cooling trend (arrow). The turning point, marking the climatic reversal, is recorded at the top of Core $397-46$, which correlates with the beginning of the rapid salt extraction in the Mediterranean. Models must be rejected which at- 


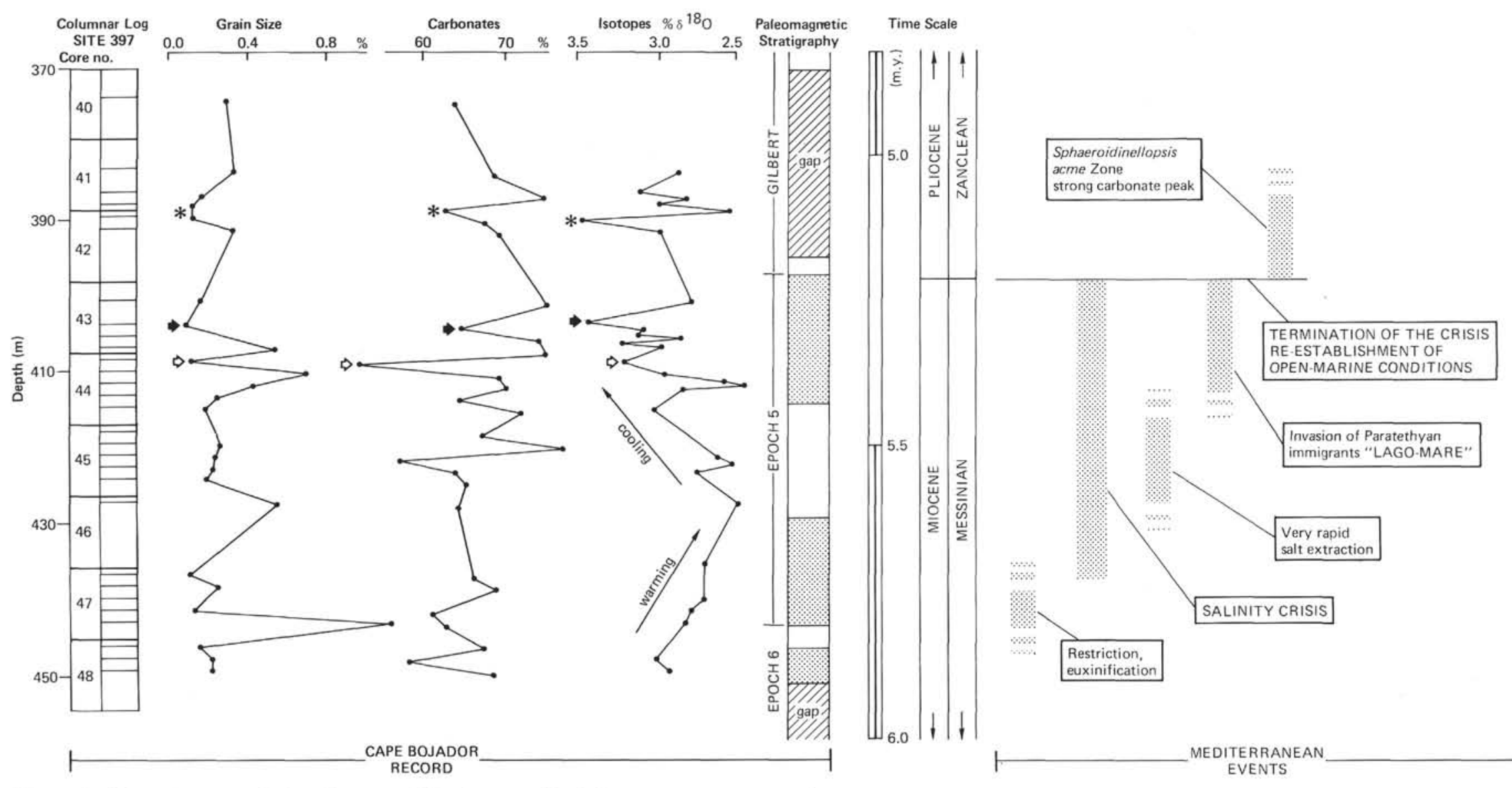

Figure 3. Variations recorded in Fraction A (column to the left), carbonate content (middle column), and isotopic ratio of oxygen measured on benthic foraminifers (column to the right) in Cores 48 through 40, DSDP Site 397. The disturbance in the pelagic realm discussed in the text as Step 2 is recorded as distinct cycles detectable in the three parameters considered, which vary sympathetically. Cycles have amplitudes which are one-third (for the isotopic signal) to twothirds (for the carbonate signal) those recorded in the latest part of the Pleistocene in the same drill site. The duration of these cycles is of the order of $1 \times 10^{5}$ $y r$. They are limited to the latest part of paleomagnetic Epoch 5, and correlate with the latest part of the Mediterranean "salinity crisis" when the Eastern Mediterranean was invaded by Paratethyan immigrants. A transition from a warming trend clearly imprinted in the isotopic signal of oxygen and a cooling trend (arrows) is recorded at approximately 430 meters sub-bottom. The climatic reversal correlates with the beginning of rapid salt extraction in the Mediterranean. 
tribute the Mediterranean salinity crisis (with or without desiccation) to glacio-eustatic lowering of sea level induced by the expansion of continental ice in Antarctica (Bandy, 1973; Nesteroff and Glaçon, 1977; Sonnenfeld, 1974; Selli, 1973; van Couvering et al., 1976). Indeed, no cooling trend is detectable in Shackleton's curve prior to the middle part of Epoch 5 characterized by a reversed polarity, i.e., more than one hundred thousand years after the onset of evaporitic conditions in the Mediterranean.

Two complete cycles (marked by short arrows in Figure 3) are recorded in the latest part of the Messinian, with the same sign in all the parameters considered. Duration is on the order of $1 \times 10^{5} \mathrm{yr}$ and amplitude, in comparison with a major late Pleistocene (glacialinterglacial) cycle, is in excess of one-third for the isotopic signal, in excess of two-thirds for the carbonate signal, and approximately one-half for the grainsize signal. These cycles, suggestive of a strong glacial influence, correlate with the latest stage of the Mediterranean salinity crisis, when the Eastern Mediterranean endoreic, depressed alkali-lakes (Cita and Ryan, 1973) were invaded by a peculiar shallow-water, euryhaline fauna immigrated from the Paratethys (Ruggieri, 1967; Sissingh, 1976; Cita et al., 1978). The maximum excursion recorded in the well-controlled (i.e., with six data points) isotopic cycle, terminating with an open arrow in Figure 3, is of such a magnitude $(0.8 \%)$ as to represent about 80 meters sea-level equivalent in stored ice (following Shackleton and Opdyke, 1977).

The new observational data strongly support the hypothesis first presented by Dreyfus and Ryan at the twenty-fourth International Geological Congress in Montreal, 1972. This hypothesis, refined by Ryan (1973) and further elaborated by Ryan et al. (1974), suggests that the salinity crisis of the Mediterranean was the cause, not the effect, of the late Miocene glacial expansion in Antarctica.

Data on clay mineral composition by Chamley et al. (this volume), and on terrigenous and residual components by Diester-Haass and by Sarnthein (both, this volume) are in good agreement with our interpretation. In particular, Sarnthein recorded an increase in glacialtype northern dust in the Messinian, whereas DiesterHaass recorded a considerable increase in glauconite from the top of Core 397-46 to Core 397-44.

\section{Step 3: Early Pliocene Steady Well-Oxygenated Stage}

Cores $397-42$ to $397-32$; sub-bottom depth: 399 to 303 meters (approximately); latest part of lithologic Unit 2; middle part of acoustic Unit 2; upper part of physical properties Unit 4, plus lower part of physical properties Unit 3; Age: Zanclean.

In these 11 cores, we recorded the consistently highest carbonate values of the entire succession; all but one of the 38 data points lie well above the mean value. After the strong disturbance related to event 2, conditions are relatively steady, but the range of change is up to 15 per cent. Due to the mediocre core recovery in several cores (for instance, Cores 397-42, 397-40,
397-36, 397-35), the curve constructed with all the data points (fig. 1 of Cita and Spezzibottiani, this volume) does not differ significantly from that averaging the value core by core (ibid., fig. 6). In general, a significant downhole increase in carbonates is recorded. This observation agrees well with the progressive downhole isotopic lightening recorded in this interval (see Shackleton and Cita, this volume). Both the carbonate peaks and the isotopic peaks in the lower part of the Pliocene approximate the values of the late Pleistocene peaks, or even exceed them.

Sediment Fractions A and B are fairly high in the upper part of the interval, then greatly decrease downhole as a consequence of dissolution at depth and incipient lithification. The dissolution measure is strongly negative throughout, whereas the rapid increase downhole of the dissolution index is clearly shown in the smoothed curves (fig. 2 and 6, Cita and Spezzibottiani, this volume).

Pyrite is conspicuously absent in this interval, as well as biogenic silica.

In summary, our observational data suggest an oceanic environment without clear evidence of definite upwelling conditions, with fairly steady conditions in terms of circulation patterns, well-oxygenated, gradually and slowly changing in terms of dissolution at depth (increasing as a function of increasing time). Sedimentation rate is higher than in the latest Miocene and increases uphole as a function of decreasing dissolution.

In the lowermost part of this interval, we point out the existence of a short duration cycle (marked by an asterisk in Figure 3 ) which is easily detectable and of the same sign in the three parameters considered, i.e., sediment Fraction A, carbonate content, and isotopic ratio of oxygen. This cycle, suggestive of a short duration "cooling" of the North Atlantic, correlates with the Sphaeroidinellopsis acme Zone of the Mediterranean (Cita, 1973b) where the highest carbonate content of the entire early Pliocene is recorded (Cita, 1973a). The Sphaeroidinellopsis acme Zone represents the sedimentary expression of the flooding of the Mediterranean desiccated or draw-down basin by deep and cold Atlantic water masses. Vertical mixing in the Western Mediterranean was so strong that it resulted in an almost identical isotopic composition recorded in benthic and planktonic foraminifers at DSDP Site 132 (van Donk et al., 1973).

We entertain the hypothesis that this short duration cycle is the physically detectable response of the North Atlantic to the re-establishment of a permanent, deepwater connection with the Mediterranean after its isolation. Unlike later times, the Mediterranean (essentially the Western Mediterranean Basin) in the early Pliocene had a deep communication with the North Atlantic, deep enough to permit the re-immigration of psychrosphaeric ostracodes (Benson, 1973; see also Hsü et al., 1977; Cita and Ryan, 1973). Consequently, the Mediterranean could not be considered the principal source of dense, salty water to the Atlantic Ocean (Rooth, 1978) at that time. 
Step 4: Onset of Upwelling Conditions of Enhanced Circulation and Progressive Climatic Deterioration in the Late Pliocene

Cores 397-31 to Section 397-15-3; sub-bottom depth: 303 to 140 meters (approximately); lithologic Unit 1B; later part of acoustic Unit 2; physical properties Units 3 (upper part) and 2 (lower part); Age: the Piacenzian stage and the topmost part of the Zanclean.

The upper boundary of Step 4 coincides with the Pliocene/Pleistocene boundary, as identified by the first evolutionary occurrence of Globorotalia truncatulinoides occurring in the lower part of a normal polarized interval, identified with the Olduvai Event (Hamilton, this volume).

Carbonate cycles are recorded throughout this interval. They are well beyond the noise level and clearly are recorded on the smoothed curve (fig. 6, Cita and Spezzibottiani, this volume). This curve is quite smooth as a result of excellent core recovery and means calculated from five or six data points for each core. The range of change is up to 25 per cent, and cycles have durations of the order or $1 \times 10^{5} \mathrm{yr}$.

Cycles are also recorded in the grain-size curves. The dissolution measure tends to increase downhole in this interval, and two discrete intervals show a positive dissolution measure (see Figure 1).

Pyrite is present in variable amounts: its abundance is maximum in the lowest part of the interval. Biogenic silica is also present, in form of tests of radiolarians and diatom frustules. All this indicates upwelling conditions and enhanced circulation at depth. We found evidence of strong reworking from older (early Pliocene) strata in Core 397-27. Evidence of submarine erosion is supported by paleomagnetic investigations (Hamilton, in Mazzei et al., this volume); the later part of the Gauss Epoch is incompletely recorded, though the missing part is so short as to be hardly detectable by means of biostratigraphic techniques alone. Acoustic horizon $\beta$ falls in this interval, providing further evidence of submarine erosion. Horizon $\beta$ has been calibrated to Core $397-24$ (see Figure 1), whereas a strong increase in terrigenous input, also attributed to enhanced erosion, is recorded in Core 397-23 (Diester-Haass, this volume).

The onset of upwelling conditions and of enhanced circulation accompanied by evidence of climatic fluctuations (carbonate cycles and isotopic cycles, see Shackleton and Cita, this volume) and of a general climatic deterioration is related to the onset of glaciation at high latitudes in the Northern Hemisphere (Ciaranfi and Cita, 1973; Cita and Ryan, 1973; Berggren and van Couvering, 1974).

The worldwide implications of this climatic event are supported by (1) the recorded occurrence of a change in diagenetic potential in pelagic carbonate sediments from the equatorial Pacific (horizon " $\alpha$ " of Schlanger and Douglas, 1974) dated at approximately 3 m.y.B.P.; and (2) the absence of sapropels, sedimentary expression of basinwide stagnation, in foraminiferal Zone M Pl 4 in the deep-sea record of the Eastern Mediterranean. This foraminiferal zone, whose upper boundary is defined by the extinction horizon of the genus Spheroidinellopsis with an interpolated age of 3 m.y.B.P. (Ryan et al., 1974) is the only interval where well-ventilated sediments are recorded throughout. The absence of sapropels extends to basinal settings, rises, and ridges, thus documenting enhanced circulation at depth east of the shallow sill separating the Eastern Mediterranean from the Western Mediterranean (Kidd et al., 1978).

Detailed studies on the isotopic composition of Globocassidulina subglobosa in Core V 28-179 from the equatorial Pacific (recently published by Shackleton and Opdyke, 1977) allow for precise location of the boundary between the steady "interglacial"-type inter$\mathrm{val}$, and the interval characterized by climatically modulated cycles whose magnitude suggests glacioeustatic changes of the order or 40 meters. The boundary falls between the Mammoth and Kaena events of the Gauss Epoch.

\section{Step 5: Early Quaternary: A Time of Upwelling and Submarine Erosion With Climatic Cycles Without Marked Cold Intervals}

Sections 397-15-2 to 397-7-3; sub-bottom depth: 140 to 60 meters (approximately); lithologic Unit 1A, partim; lower part of acoustic Unit 2 plus lower part of acoustic Unit 1; physical properties Unit 2 (later part); Age: early Pleistocene.

This interval extends from the Olduvai event of the Matuyama up to the lowermost part of the Brunhes.

Acoustic horizon $\alpha$, the strongest recorded in the late Neogene succession under discussion, falls within this interval.

The boundary between Steps 4 and 5 is quite arbitrary: it has been located at the Pliocene/Pleistocene boundary (see Hays and Berggren, 1971) to show how irrelevant this chronostratigraphic boundary is in terms of evolution of ocean paleoenvironment in the open ocean.

The Pliocene/Pleistocene boundary, as identified here, correlates with the Pliocene/Pleistocene boundary at stratotypes in the Mediterranean (Selli, 1967). This follows the suggestions of the Eighteenth International Geological Congress, which stated that that boundary should be defined in the field in correspondence with the first record of "northern guests" in the Mediterranean (see Committee for the Study of the Pliocene/ Pleistocene boundary, Intern. Geol. Congress, Great Britain, 1948, Reports, v. 9, no. 6).

Following this principle, the Pliocene/Pleistocene boundary stratotype has been located in the Le Castella section of Calabria at the level where the first occurrence of the benthic foraminifer Hyalinea baltica is recorded (Emiliani et al., 1961). Many objections have been raised against the choice of the section, because of poor exposure, slumping, reworking, etc. (see Smith, 1969; Bandy and Wilcoxon, 1970; Bayliss, 1975). Rio (1974) and, more recently, Haq et al. (1977) arrived at the conclusion that the estimated age of the boundary is 1.6 instead of 1.8 m.y.B.P. on the basis of nannoplankton biostratigraphy. The correlation, though based on multiple overlapping criteria, is indirect, and we find no 
satisfactory basis for their conclusions that ". . . the Pliocene/Pleistocene boundary is thus coeval with the earliest of four major climatic deteriorations in the Pleistocene, reconciling paleoclimatic concepts with the chronostratigraphic definition of the epoch" (Haq et al., 1977).

This revised age for the Pliocene/Pleistocene boundary is contradicted by new radiometric age determinations presented at the Tenth INQUA Congress in Birmingham, 1977, by Savelli and Mazzetti (1977) and by Boellestorff (1977). The new age determinations range from 2.3 to 2.0 m.y.B.P. and are from the Vrica section, proposed at the same Tenth INQUA Congress as boundary-stratotype in substitution of that designated at Le Castella. The biostratigraphic correlation between the two sections is still tentative. The first "northern guest" recorded in the Vrica section is the ostracode Cyteropteron testudo (Colalongo and Pasini, 1977) which apparently predates the first record of Hyalinea baltica.

The first "northern guest" entering the Mediterranean, according to Ruggieri et al. (1975) is Arctica islandica. In the Santerno section of northern Italy, its first occurrence is recorded several hundred meters beneath that of Hyalinea baltica, the depositional environment being suitable for both species (Ruggieri, 1975). The first record of $A$. islandica coincides with a magnetically positive event of the Matuyama Epoch, referred to as "Reunion" by Nakagawa and Kukla (1975) and calibrated at 2 to $2.1 \mathrm{~m} . \mathrm{y}$. B.P.

In the Stirone section, also from northern Italy, the same stratigraphically low occurrence of Arctica islandica is recorded (Pelosio and Raffi, 1977), referred to by Venzo (1975, footnote, p. 437) as "Stironian"' glacial phase, and corresponding to the Reunion event (Kukla and Pelosio, personal communication, 1977).

The deep-sea record of the Mediterranean across the Pliocene/Pleistocene boundary could be investigated in the continuously cored successions recorded in the Tyrrhenian Basin (DSDP Site 132) and in the Ionian Basin (DSDP Site 125); see Cita et al. (1973). Both in the Tyrrhenian Basin of the Western Mediterranean and in the Ionian Basin of the Eastern Mediterranean, we found clear evidence of paleontologically detectable climatic fluctuations in the early Pleistocene and in the late Pliocene (Ciaranfi and Cita, 1973), no major cooling being recorded at or near the boundary at either site (ibid., see also Cita and Ryan, 1973).

At Cape Bojador, climatic cycles are recorded both in the isotopic signal and in the carbonate signal. Their amplitude and duration is comparable to those recorded in the late Pliocene (Step 4 of our model). The climatic deterioration continues without any indication of major cooling, as also shown by the quantitative micropaleontological studies on test intervals 2 versus 3 (see Table

1). In other words, the new evidence provided by DSDP Site 397 supports and strengthens the evidence previously available, that there are two levels indicative of marked climatic change (deterioration) in the last four million years. One is late Pliocene in age, starting in the Gauss Paleomagnetic Epoch (see also Shackleton and Opdyke, 1977), which coincides with the onset of glacial conditions and with expansion of continental ice at high latitudes in the Northern hemisphere (see Step 4 of our model). The second marked cooling starts near the base of the Brunhes paleomagnetic Epoch, in the late Pleistocene, where we have evidence of really "cold" episodes comparable in magnitude to the last Glacial. The latter climatic deterioration coincides with Step 6, whose cycles recorded in all the parameters considered (Figure 1; see also Shackleton and Cita; Cita and Spezzibottiani; both, this volume) display the highest amplitudes, with evidence of the "coldest" conditions ever recorded in the area.

No climatic change, however, coincides with the Pliocene/Pleistocene boundary.

If we follow the "northern guests" philosophy discussed above, instead of the conventional boundary, the Pliocene/Pleistocene boundary calibrated at approximately 2.0 m.y.B.P. would fall in Core $397-19$, in coincidence with the extinction horizon of Globorotalia miocenica. A marked cool cycle is recorded in the isotopic signal (Shackleton and Cita, this volume) at this level, which falls (a) near the termination of an inferred cooling trend suggested by the dissolution measure (Figure 1, left) and (b) near the base of an interval characterized by low and steady grain size and by high and rapidly fluctuating disslution ratio (Figure 1, right).

\section{Step 6: Evidence of High-Amplitude Climatic Cycles and of Strong Climatic Deterioration in the Late Pleistocene}

Sections 397-7-2 to 397-1-1; sub-bottom depth: 60 meters to the sea bed; lithologic Unit 1A, partim; upper part of acoustic Unit 1; physical properties Unit 1, Age: late Pleistocene.

The poor recovery of Core $397-1$ and the watery character of the sediment prevented the recognition of the Holocene and of the youngest part of the Pleistocene.

As mentioned before, in this latest interval we recorded the largest variations in all the parameters considered, including faunal changes (see Table 1 and Figure 1).

Sedimentation rate is high and presumably changes from the cold periods, where the terrigenous input is maximum (Diester-Haass, this volume) to the warm periods, where it decreases considerably. The frequency of our sampling, however, prevents a firm statement.

The major cycles recorded in this interval are at least five and their duration is of the order of $1 \times 10^{5} \mathrm{yr}$. Conditions as warm as those recorded in the topmost sample investigated Section 397-1-1, which we consider a reference sample, are found in only two levels based on the isotopic signal. Five levels, one per core from Core $397-2$ to $397-6$ inclusive, display strong positive isotopic values suggestive of real "glacial" conditions.

These conclusions agree well with previous knowledge of the late Pleistocene, provided by very detailed investigations on a number of North Atlantic piston cores (CLIMAP, 1976). 


\section{ACKNOWLEDGMENTS}

Discussions with Allan Be', Wolf Berger, Liselotte DiesterHaass, George Kukla, Andy McIntyre, Giovanni Pelasio, B. Rooth, Bill Ruddiman, Giuliano Ruggieri, Michael Sarnthein, and Nick Shackleton have been of great benefit.

We thank Alberto Malinverno and Nicola Sironi for technical assistance.

\section{REFERENCES}

Adams, C. G., Benson, R. H., Kidd, R. B., Ryan, W. B. F., and Wright, R. C., 1977. The Messinian salinity crisis and evidence of late Miocene eustatic changes in the world ocean, Nature, v. 269, p. 383-386.

Bandy, O. L., 1966. Faunal evidence of Miocene-to-Recent paleoclimatology in Antarctic, Am. Assoc. Petrol. Geol. Bull., v. 50, p. 643-644.

1973. Chronology and paleoenvironmental trends, late Miocene-early Pliocene, western Mediterranean. In Messinian events in the Mediterranean: Amsterdam (North-Holland), p. 21-25.

Bandy, O. L. and Wilcoxon, J. A., 1970. The PliocenePleistocene boundary, Italy and California, Geol. Soc. Am. Bull., v. 81, p. 2939.

Bayliss, D. D., 1975. The stratigraphy of the type section of the Pliocene/Pleistocene boundary in Italy. In Late Neogene epoch boundaries: Micropaleontology Press Spec. Publ., p. 31-40.

Benson, R. H., 1973. Psychrosphaeric and continental ostracoda from ancient sediments in the floor of the Mediterranean. In Ryan, W. B. F., Hsü, K. J., et al., Initial Reports of the Deep Sea Drilling Project, v. 13, Part 2: Washington (U.S. Government Printing Office), p. 1002-1008.

Berger, W. H. and von Rad, U., 1972. Cretaceous and Cenozoic sediments from the Atlantic Ocean. In Hayes, D. E. Pimm, A.C., et al., Initial Reports of the Deep Sea Drilling Project, v. 14: Washington (U.S. Government Printing Office), p. 788-854.

Berggren, W.A. and Haq, B., 1976. The Andalusian stage (late Miocene): biostratigraphy, biochronology and paleoecology, Palaeogeogr., palaeoclimat., palaeoecol., v. 20 , p. $67-129$.

Berggren, W. A. and van Couvering, J. A., 1974. The late Neogene, biostratigraphy, geochronology and paleoclimatology of the last 15 million years in marine and continental sequences, Palaeogeogr., Palaeoclimat., Palaeoecol., v. 16, p. 1-216.

Boellestorff, J., 1977. The Pliocene/Pleistocene boundary in the central Great Plains, U.S.A., Tenth INQUA, Congr., Birmingham 1977, p. 37. (Abstracts).

Ciaranfi, N. and Cita, M.B., 1973. Paleontological evidence of changes in the Pliocene climates. In Ryan, W.B.F., Hsü, K. J., et al., Initial Reports of the Deep Sea Drilling Project v. 13, Part 2: Washington (U. S. Government Printing Office), p. 1387-1399.

Cita, M.B., 1973a. Mediterranean evaporite: Paleontological arguments for a deep-basin desiccation model. In Messinian events in the Mediterranean: Amsterdam (NorthHolland), p. 206-228.

1973b. Pliocene biostratigraphy and chronostratigraphy. In Ryan, W.B.F., Hsü, K.J., et al., Initial Reports of the Deep Sea Drilling Project, v. 13, Part 2: Washington (U.S. Government Printing Office), p. 1343-1379.

1975. The Miocene/Pliocene boundary: history and definition. In Late Neogene epoch boundaries: Micropaleontology Press Spec. Publ. l, p. 1-24.

1977. The response of the North Atlantic to the Mediterranean salinity crisis, as recorded on the northwest
African margins, IGCP project 96, Messinian Seminar 3. (Abstracts).

1978. Lacustrine and hypersaline deposits in the deep sea and their bearing on paleoenvironments and paleoecology: The Ewing Symposium, p. 9-10. (Abstracts).

Cita, M.B. and Ryan, W.B.F., 1973. The Pliocene record in deep-sea Mediterranean sediments. 5. time-scale and general synthesis. In Ryan, W.B.F., Hsü, K.J., et al., Initial Reports of the Deep Sea Drilling Project, v. 13, Part 2: Washington (U.S. Government Printing Office), p. 1405-1416.

1978. The Bou Reg Reg Section of the Atlantic Coast of Morocco. Evidence, timing and significance of a late Miocene regressive phase, Riv. Ital. Paleontol. Strat., v. 84 , no. 4 .

Cita, M.B., Chierici, M.A., Ciampo, G., Moncharmont Zei, M., d'Onofrio, S., Ryan, W.B.F., and Scorziello, R., 1973. The Quaternary Record in the Ionian and Tyrrhenian Basins of the Mediterranean Sea. In Ryan, W.B.F., Hsü, K.J., et al., Initial Reports of the Deep Sea Drilling Project v. 13, Part 2: Washington (U.S. Government Pringing Office), p. 1380-1390.

Cita, M. B., Ryan, W. B. F., and Hamilton, N., 1977. Pleistocene and Pliocene deep-sea successions off Cape Bojador, North Atlantic, Tenth INQUA Congr., Birmingham 1977, p. 80. (Abstracts).

Cita, M.B., Wright, R.H., Ryan, W.B.F., and Longinelli, A., 1978. Messinian paleoenvironments. In Hsü, K.J., Montadert, L., et al., Initial Reports of the Deep Sea Drilling Project, v. 42, Part I: Washington (U. S. Government Printing Office), p. 1003-1036.

CLIMAP Project Members, 1976. The surface of the ice-age earth, Science, v. 191, p. 1131-1137.

Colalongo, M.L. and Pasini, G., 1977. The Vrica Section (Calabria, Italy). Ostracoda distribution and their importance for the Neogene/Quaternary boundary, Tenth INQUA Congr., Birmingham, 1977, p. 90. (Abstracts).

Debenedetti, A., in press. Messinian salt deposits in the Mediterranean: evaporites or precipitates?, Boll. Soc. Geol. Ital.

Diester-Haass, L., 1977. Radiolarian/planktonic foraminiferal ratio in a coastal upwelling region, J. Foram. Res., v. 7, p. 36-53.

Emiliani, C., Mayedaa, T., and Selli, R., 1961. Paleotemperature analysis of the Plio-Pleistocene section at Le Castella, Calabria, southern Italy, Geol. Soc. Am. Bull., v. 72, p. 679-688.

Fairbridge, R. W., 1966. Encyclopedia of oceanography: New York (Reinhold Publishing Corporation), p. 1-1021.

Haq, B.U., Berggren, W.A., and van Couvering, J.A., 1977. Corrected age of the Pliocene/Pleistocene boundary, $\mathrm{Na}$ ture, v. 269, p. 483-488.

Hayes, D.E., Frakes, L.A., et al., 1975. Initial Reports of the Deep Sea Drilling Project, v. 28: Washington (U.S. Government Printing Office).

Hays, J.D. and Berggren, W.A., 1971. Quaternary boundaries and correlations. In Micropaleontology of the oceans: Cambridge (Cambridge Univ. Press), p. 669-691.

Hsü, K.J., Cita, M.B., and Ryan, W.B.F., 1973. The origin of the Mediterranean evaporite. In Ryan, W.B.F., Hsü, K.J., et al., Initial Reports of the Deep Sea Drilling Project, v. 13, Part 2: Washington (U.S. Government Printing Office), p. 1203-1232.

Hsü, K.J., Montadert, L., Bernoulli, D., Cita, M.B., Erickson, A., Garrison, R.E., Kidd, R.B., Mélières, F., Müller, C., and Wright, R.H., 1977. History of the Mediterranean salinity crisis, Nature, v. 267 , p. $399-403$. 
Kennett, J.P., 1967. Recognition and correlation of the Kapitean Stage (upper Miocene), New Zealand, New Zealand J. Geol. Geophys., v. 10, p. 1051-1063.

Kidd, R.B., Cita, M.B., and Ryan W.B.F., 1978. Stratigraphy of Eastern Mediterranean sapropel sequences recovered during DSDP Leg $42 \mathrm{~A}$ and their paleoenvironmental significance. In Hsü, K.J., Montadert, L. et al., Initial Reports of the Deep Sea Drilling Project, v. 42, Part 1: Washington (U. S. Government Printing Office), p. 421663.

Nakagawa, H. and Kukla, G., 1975. Late Cenozoic magnetostratigraphy, Guidebook, INQUA Subcommission Mediterranean Shorelines, Meeting 1975.

Nesteroff, W.D. and Glaçon, G., 1977. Le caracteré rythmique des evaporites messiniennes en Mediterranée orientale (Coupe d'Eraclea Minoa, Sicile), Bull. Soc. Géol. France, v. 19 , p. $489-500$.

Pelosio, G. and Raffi, S., 1977. Preliminary remarks on mollusc assemblages of the Stirone River Pleistocene series (Parma Province, Northern Italy), Tenth INQUA Congr., Birmingham, 1977. (Preprint).

Rio, D., 1974. Remarks on late Pliocene-early Pleistocene calcareous nannofossils stratigraphy in Italy. Ateneo Parmense Acta Naturalia, v. 10, p. 409-449.

Rooth, C., 1978. Hydrology and ocean circulation. Some possible paleo-oceanographic scenarios, The Ewing Symposium, p. 29. (Abstracts).

Ruggieri, G., 1967. The Miocene and later evolution of the Mediterranean Sea. Aspects of Tethyan biogeography, Syst. Assoc. Publ. 7, p. 2833-290.

Ruggieri, G., 1975. Sull'ordine di comparsa degli “ospiti nordici" nella sezione pleistocenica del Santerno, Boll. Soc. Geol. Ital., v. 94, p. 1603-1611.

Ruggieri, G., Buccheri, G., Greco, A., and Sprovieri, R., 1975. Un affioramento di Siciliano nel quadro della revisione della stratigrafia del Pleistocene inferiore, Boll. Soc. Geol. Ital., v. 94, p. 889-914.

Ryan, W.B.F., 1973. Geodynamic implications of the Messinian crisis of salinity. In Messinian events in the Mediterranean: Amsterdam (North-Holland), p. 26-38.

1978. Messinian badlands on the south-eastern margin of the Mediterranean Sea, Mar. Geol., v. 27, p. 349-364.

Ryan, W.B.F. and Cita, M.B., 1978. The nature and distribution of Messinian erosional surfaces - indicators of a several-kilometers-deep Mediterranean in the Miocene, Mar. Geol., v. 27, p. 193-230.

Ryan, W.B.F., Cita, M.B., Dreyfus Rawson, M., Burckle, L.H., and Saito, T., 1974. A paleomagnetic assignment of Neogene stage boundaries and the development of isochronous datum planes between the Mediterranean the Pacific and Indian Oceans in order to investigate the response of the World Ocean to the Mediterranean "salinity crisis," Riv. Ital. Paleontol. Strat., v. 80, p. 631-688.

Saito, T., Burckle, L.H., and Hays, J.D., 1975. Late Miocene to Pleistocene biostratigraphy of equatorial Pacific sediments. In Late Neogene epoch boundaries: Micropaleontology Press Spec. Publ. I, p. 226-244.

Savelli, C. and Mazzetti, R., 1977. The Vrica Section (Calabria, Italy). K/Ar age and petrographic characters of the "volcaniclastic" layer. Tenth INQUA Congr., Birmingham, 1977, p. 400. (Abstracts).

Schlanger, S.O. and Douglas, R.G., 1974. The pelagic oozechalk-limestone transition and its implications for marine stratigraphy, Spec. Publ. Int. Assoc. Sedimentol., v. 1, p. 117-148.

Selli, R., 1967. The Pliocene-Pleistocene boundary in Italian marine sections and its relationship to continental stratigraphies. Progress in oceanography: New York (Pergamon Press), v. 4, p. 67-86.

1973. Il Mediterraneo nel Miocene superiore: un mare sovrasalato, Le Scienze, no. 56, p. 20-21.

Shackleton, N.J. and Opdyke, N.D., 1977. Oxygen isotope and paleomagnetic evidence for early Northern Hemisphere glaciation, Nature, v. 270, p. 216-219.

Sissingh, W., 1976. Aspects of the Late Cenozoic evolution of the South Aegean ostracode fauna, Palaeogeogr., Palaeoclim., Palaeoecol., v. 20, p. 131-145.

Smith, L.A., 1969. Pleistocene discoasters at the stratotype of the Calabrian stage (Santa Maria di Catanzaro) and at Le Castella, Italy, Gulf Coast Assoc. Geol. Soc. Trans., v. 19, p. 579-583.

Sonnenfeld, P., 1974. The Upper Miocene evaporite basins in the Mediterranean region. A study in paleo-oceanography, Geol. Rundsch., p. 1133-1172.

Stainforth, R.M., Lamb, J.L., Luterbacher, H.P., Beard, J.H., and Jeffords, R.M., 1975. Cenozoic planktonic foraminiferal zonation and characteristic index forms, The Kansas University Paleontol. Contrib., Article 62, p. 1-425.

Thiede, J., 1977. Aspects of the variability of the Glacial and Interglacial North Atlantic eastern boundary current (last 150,000 years), "Meteor"' Forsch.-Ergebnisse, no. 28, p. 1-36.

Vail, P.R. and Mitchum, R.M., 1978. North Atlantic sea-level changes, The Ewing Symposium, p. 41-41. (Abstracts).

van Couvering, J.A., Berggren W.A., Drake, R.E., Aguirre, E., and Curtis, G.H., 1976. The terminal Miocene event, Mar. Micropaleontol., v. 1, p. 263-286.

van Donk, J., Saito, T., and Shackleton, N.J., 1973. Oxygen isotopic composition of benthonic and planktonic foraminifera of earliest Pliocene age at Site 132 - Tyrrhenian Basin. In Ryan, W.B.F., Hsu, K.J., et al., Initial Reports of the Deep Sea Drilling Project, v. 13, Part 2: Washington (U.S. Government Printing Office), p. 798-800.

Venzo, S., 1975. Remarks on the stratigraphic and paleontological sequence of the proposed Plio-Pleistocene boundary type section of Le Castella (Calabria, Italy), L'Ateneo Parmense, Acta Naturalia,v. 11, p. 423-447.

Weyl, P.K., 1968. The role of the oceans in climatic change: A theory of the ice ages, Meteorological Monographs, v. 8, p. $37-60$.

Winterer, E.L., Riedel, W.R., et al., 1971. Initial Reports of the Deep Sea Drilling Project, v. 7: Washington (U.S. Government Printing Office).

Winterer, E.L., Ewing, J.I., et al., 1973. Initial Reports of the Deep Sea Drilling Project, v. 17: Washington (U. S. Government Printing Office). 